\title{
Regional Capital Mobility within Bulgaria
}

\section{Yannick Bineau*}

Faculty of Economics and Social Sciences, University of Science and Technology, France

\begin{abstract}
This paper investigates regional savings-investment correlation between 1999 and 2009 within the small and highly open economy of Bulgaria. Results confirm low correlation between regional savings and investment rates. Regional capital mobility has increased over time and openness has a positive effect on regional investment.
\end{abstract}

Keywords: Bulgaria; Domestic savings; Feldstein-horioka puzzle; Regional data; Panel data

\section{Introduction}

Feldstein and Horioka [1] estimate the correlation between savings and investments for a sample of 16 OECD countries. They conclude that almost $85 \%$ to $95 \%$ of domestic savings were locally invest, suggesting low international capital mobility. These results have led to much research [2-5]. One area focuses on empirical issues with regional data [6-13]. Most studies conclude that intra-national capital mobility is high because the regions are more integrated, whereas nations appear relatively closed $[14]^{1}$. The correlation coefficients are lower or even negative when compared to OECD countries where frontier effects induce stronger integrated goods markets within countries rather than between them [15], GDP per capital are high, financial systems are intensively developed and openness appears important.

This paper contributes to the FH literature in two ways. First, there are no studies focusing on regional data of Bulgaria, a single small open newcomer EU member, characterized by the lowest average GDP per capita among EU-272. Secondly, the standard FH representation is amended by introducing two new variables: an interactive time trend with the savings rate takes into account the impact of policy measures on savings behavior and intra-national capital mobility, and a regional openness variable is included to estimate the effect of openness on investment rate. This specification is tested with pooled ordinary least squares, fixed effects and random effects models.

The structure of the paper is the following. The second section presents the data and the methodology. Result details the empirical results. Concluding Remarks

\section{Data and Methodology}

Original data was extracted from various Annual Statistical Yearbooks published from the National Statistical Institute of Bulgaria. The availability of this regional data is reduced and spans from 1999 to 2009. Twenty-eight provinces were organized, as a response to the EU enlargement requirement in January $1999^{3}$. The addition of these districts creates six regions ${ }^{4}$. Precise direct calculation of regional savings is not possible, because regional consumption data are not available. The assumption is made that regional savings is a constant

\footnotetext{
${ }^{1} \mathrm{~A}$ recent meta-analysis on the $\mathrm{FH}$ literature shows that regional data based studies estimate a systematic lower or even negative effect.

2 the average GDP per capita is established at 45 in 2011 (EU-27=100). http://epp. eurostat.ec.europa.eu

3 Administrative territorial unit districts were implemented when "Territorial Organization Act of the Republic of Bulgaria" came into force on 5th January, 1999 ${ }^{4}$ Details of those regions is available at: http://en.wikipedia.org/wiki/NUTS_of_ Bulgaria
}

part of national savings and is proportional to the ratio of regional gross domestic product (GDP) to national GDP. Savings is defined as follows:

$$
S_{i, t}=\left(\frac{Y_{i, t}}{Y_{t}}\right) \cdot S_{t}(\mathrm{i}=1, \ldots 6) \quad(\mathrm{t}=1999, \ldots 2009)
$$

Where $S$ and $Y$ are savings and GDP, respectively, and $i$ and $t$ describe Bulgarian regions and years, respectively. The GDP at the country level is the sum of the regional GDP. To assess the level of capital mobility within this country, the seminal long-run FH equation is modified. It introduces an interactive time trend and an openness variable and has the following form:

$$
\left(\frac{I_{i, t}}{Y_{i, t}}\right)=\alpha_{i, t}+\beta_{1}\left(\frac{S_{i, t}}{Y_{i, t}}\right)+\beta_{2}\left(\operatorname{Tr}_{t} \times \frac{S_{i, t}}{Y_{i, t}}\right)+\beta_{3} O p_{i, t}+\mu_{i, t}
$$

Where $\left(I_{i, t} / Y_{i, t}\right)$ denotes the (log) ratio of gross capital formation to GDP of Bulgarian region $i$ at time $t$, and $\left(S_{i, t} / Y_{i, t}\right)$ refers to the $(\log )$ ratio of savings to GDP of Bulgarian region $i$ at time $t$. The time trend is defined by $\mathrm{T} r$. The variable $\mathrm{O} p$ makes reference to (log) regional openness ratio. Greek letter $\mu$ stands for an error term $\left(\mu_{i t} \sim\left(0, \sigma^{2}\right)\right)$. The regional heterogeneity is captured by the region-specific coefficient $\alpha_{i, t}$.

The degree of international capital mobility is defined by the value of the savings retention coefficient $\beta_{1}$. If estimate of $\beta_{1}$ is low, then the link between regional savings and investment rates is not important. Intra-national capital mobility is high, which may imply financial integration. On the opposite, a high level of $\beta_{1}$ suggests low regional capital mobility.

An interactive time trend with savings is included [16-19]. It considers, as noted by Kasuga [20] that the financial structure can have an effect on the saving-investment correlation coefficient as a consequence of policy measures undertaken by Bulgarian authorities, and modifications of habit consumption. A negative estimate of $\beta_{2}$ indicates that regional capital mobility increases during the period. An likely explanation if $\beta_{2}$ is significantly negative is the fact that local

*Corresponding author: Yannick Bineau, University of Science and Technology - Faculty of Economics and Social Sciences, France, Tel: + 85512812482; E-mail: yannick.bineau@univ-lille1.fr

Received April 09, 2014; Accepted May 06, 2014; Published May 15, 2014

Citation: Bineau Y (2014) Regional Capital Mobility within Bulgaria. J Glob Econ 2: 112. doi:10.4172/2375-4389.1000112

Copyright: (c) 2014 Bineau Y. This is an open-access article distributed under the terms of the Creative Commons Attribution License, which permits unrestricted use, distribution, and reproduction in any medium, provided the original author and source are credited. 
credit market is strongly developing and is perceived as a crucial feature for intra-national capital mobility [21,22].

According to Wong [23], openness can influence the savings retention coefficient. The regional openness variable is constructed as the product of the average of trade flows as a percentage of regional GDP and gives information about the effect of trade on the investment ratio. A positive estimate of $\beta_{3}$ indicates that any changes in openness exert a similar impact on the regional investment rate and on the domestic economy.

\section{Results}

For comparative purposes, Table 1 presents the results of two expressions of equation (2). Columns (1) through (3) refer to the standard $\mathrm{FH}$ relation. Interactive time trends with savings rates and openness effects are excluded. Columns (4) through (6) include all effects. Pooled ordinary least squares (POLS), the fixed effect model (FEM) and the random effects model (REM) are employed to check for robustness ${ }^{5}$.

The POLS regression is estimated on the cross-sectional time-series data for all regions. In column (1), coefficient $\mathrm{R}^{2}$ is 0.73 . The savingsinvestment correlation coefficient is significant at the 1 percent level. The point estimate, at 0.555 , suggests that regional capital mobility is weak. Any changes in the savings rate have a large positive impact on the investment rate. However, the POLS model is a restricted model, since it tries to capture heterogeneity across individual regions, which is constant over time, estimating only one overall intercept for the whole panel: $\alpha_{i, t}=\alpha$. It is unlikely that all regions will have identical intercepts, even if this methodology yields consistent and efficient estimates of both the intercept and slope.

In FEM, the heterogeneity across regions is due to parametric shifts of the regression function captured by $\alpha_{i, t}=\alpha_{i}$. The advantage of FE over POLS is that the presence of time-invariant, regional-specific effects can be tested. To be able to choose between both models, a Fisher test for a single intercept versus intercepts unique to each region is used. The calculated F statistics, established at 96.81 is significant. The restrictive assumption of homogeneity of the constant from the POLS model is rejected. This model is not adequate to this regional data and could cause misleading interpretations. On the other hand, the REM assumes

${ }^{5}$ Number of years $(T=10)$ is larger than number of regions $(N=6)$. However, the number of points is too limited to adopt unit root tests and cointegration techniques. that the country-specific effect is randomly distributed $\left(\omega_{i, t} \mu_{i, t}+\varepsilon_{i, t}\right)$ and the constant is $\alpha_{i t}=\alpha$. Intra-capital mobility is low, because the estimated saving-investment coefficient is 0.571 and significant. The Hausman specification test is implemented to determine whether REM is rejected over the FEM. The results suggest that REM could give more appropriate results.

Results from the extended FH model are presented in columns (4) through (6). The savings investment correlation coefficients of the extended regressions are significant, positive and very high for the POLS as for the RE models Compared to columns (1) and (3), this supports the strong regional saving-investment correlations. However, the regression coefficient from FE estimation is 0.149 and significant. This estimated impact is low compared to columns (4) and (6) and lower than equation (2).

The calculated F statistics is 117.68 and significant. Thus, the FE model gives better estimations than the POLS model. On the other hand, the statistics of the Hausman test is significant. This confirms that the REM is rejected over the FEM. Therefore, both tests support the assumption that an FEM is preferred to the POLS and REM. OLS estimations are used to investigate equation (2) and to discuss column (5) where heterogeneity persists.

The sign of the interactive time trend with the savings rate is negative and significant (estimated impact: -0.086 ). Structural policy measures adopted by national authorities lead to an increase of intra-national capital mobility over the period, even if the impact on the investment rate is low, compared to the savings rate correlation coefficient. Thus, the important reforms of the financial system over this period leading to an increase in its capacity to collect savings could favor higher intra-national capital mobility. However, while recently implemented economic policy measures appear to promote regional capital mobility, openness has an important positive impact on the regional investment rate. The point estimate is positive and statistically significant: any one percent change in openness induces a change of regional investment rate by $0.47 \%$. Openness increases international competition, which stimulates the investment rate.

\section{Concluding Remarks}

This paper uses regional data for Bulgaria to measure savingsretention coefficients. Different models are implemented to extended $\mathrm{FH}$ specification. The FEM is the most suitable to the data and gives

\begin{tabular}{|c|c|c|c|c|c|c|}
\hline & (1) & (2) & (3) & (4) & (5) & (6) \\
\hline & POLS & FE & RE & Pooled & FE & RE \\
\hline $\boldsymbol{\beta}_{0}$ & $\begin{array}{c}3.540^{* * *} \\
(0.045)\end{array}$ & $\begin{array}{c}3.223^{* * *} \\
(0.151)\end{array}$ & $\begin{array}{c}3.544^{* * *} \\
(0.449)\end{array}$ & $\begin{array}{c}2.945^{\star * *} \\
(0.366)\end{array}$ & $\begin{array}{c}2.990^{* * *} \\
(0.125)\end{array}$ & $\begin{array}{c}3.348^{* * *} \\
(0.359)\end{array}$ \\
\hline $\boldsymbol{\beta}_{1}$ & $\begin{array}{l}0.555^{\star *} \\
(0.040)\end{array}$ & $\begin{array}{l}0.268^{* *} \\
(0.120)\end{array}$ & $\begin{array}{l}0.571^{* *} \\
(0.274)\end{array}$ & $\begin{array}{c}0.874^{* * *} \\
(0.197)\end{array}$ & $\begin{array}{c}0.146^{\star * *} \\
(0.067)\end{array}$ & $\begin{array}{c}0.936^{\star * *} \\
(0.182)\end{array}$ \\
\hline $\boldsymbol{\beta}_{2}$ & & & & $\begin{array}{c}-0.106^{* * *} \\
(0.009)\end{array}$ & $\begin{array}{c}-0.086^{* * *} \\
(0.006)\end{array}$ & $\begin{array}{c}-0.098^{* * *} \\
(0.010)\end{array}$ \\
\hline $\boldsymbol{\beta}_{3}$ & & & & $\begin{array}{c}-0.286^{* *} \\
(0.170)\end{array}$ & $\begin{array}{c}0.471^{* * *} \\
(0.097)\end{array}$ & $\begin{array}{c}0.033^{* * *} \\
(0.174)\end{array}$ \\
\hline $\mathbf{R}^{2 \mathrm{C}}$ & 0.734 & 0.903 & & 0.878 & 0.941 & \\
\hline $\mathbf{F}$ & $177.003^{* *}$ & & & $157.561^{* * *}$ & & \\
\hline$\sigma_{\varepsilon}$ & & & 0.439 & & & 0.220 \\
\hline$\rho$ & & & 0.326 & & & 0.385 \\
\hline F-test for POLS/FE & $96.81^{\star \star \star}$ & & & $117.69^{\star \star \star}$ & & \\
\hline Hausman test & & & 0.001 & & & $25.55^{\star * *}$ \\
\hline
\end{tabular}

Note: The White cross-section standard errors are in parentheses below the estimated coefficients.

Significance at 1 percent, 5 percent, and 10 percent levels are reported by ${ }^{\star \star *}$, ${ }^{* \star}$, and ${ }^{*}$, respectively.

Table 1: Saving-investment specifications. 
significant and positive but low savings-retention coefficients. This also finds that intra-national capital mobility has been increasing. Results show that a larger openness supplements domestic investment. Ultimately, further research could test the assumption that the increase in domestic capital stock may affect Bulgaria's competitiveness through technical progress and enhance the economic region's catch-up process.

\section{References}

1. Feldstein M, Horioka C (1980) Domestic saving and international capital flows. Econ J 90: 314-329.

2. Frankel JA (1992) Measuring international capital mobility: A review. Am Econ Rev 82: 197-202.

3. Coakley J, Kulasi F, Smith R (1998) The Feldstein-Horioka puzzle and capital mobility: a review. Int J Financ Econ 3: 169-188.

4. Obstfeld M (1994) International capital mobility in the 1990s.

5. Apergis N, Tsoumas C (2009) A survey of the Feldstein-Horioka puzzle: What has been done and where we stand. Res Econ 63: 64-76.

6. Bayoumi TA, Rose AK (1993) Domestic savings and intra-national capital flows. Eur Econ Rev 37: 1197-1202.

7. Decressin J, Disayatat $P(2000)$ Capital markets and external current accounts: what to expect from the euro.

8. Helliwell JF, McKitrick R (1999) Comparing capital mobility across provincial and national borders. Can J Econ 32: 1164-1173.

9. Yamori N (1995) The relationships between domestic savings and investment: the Feldstein-Horioka test using regional data. Econ Lett 48: 361-366.

10. Dekle R (1996) Saving-investment associations and capital mobility: on evidence from Japanese regional data. J Int Econ 41: 53-72.

11. Sinn S (1992) Saving-investment correlations and capital mobility: On the evidence form annual data. Econ J 102: 1162-1170.
12. Li C (2010) Savings, investment, and capital mobility within China. China Econ Rev 21: 14-23.

13. Chan KS, Dang QT, Lai JT, Yan IKM (2011) Regional capital mobility in China 1978-2006. J Int Money Financ 30: 1506-1515.

14. Bineau Y (2010) Une méta-analyse des études sur la mesure de la mobilité internationale du capital selon la méthode macro-économique de Feldstein et Horioka. L Actualité Economique 86: 227-272.

15. Parsley DC, Wei SJ (2001) Explaining the border effect: the role of exchange rate variability, shipping costs, and geography. J Int Econ 55: 87-105.

16. Montiel PJ (1994) Capital mobility in developing countries: some measurement issues and empirical estimates. World Bank Econ Rev 8: 311-353.

17. Isaksson A (2001) Financial liberalisation, foreign aid, and capital mobility: evidence from 90 developing countries. J Int Financ Markets Inst Money 11: 309-338.

18. Kumazawa R, Payne J (2005) Additional panel data evidence on the savinginvestment relationship and foreign aid in LDCs. Front Financ Econ 2: 59-66.

19. Payne J, Kumazawa R (2005) Capital mobility, foreign aid, and openness: Further panel data evidence from Sub-Saharan Africa. J Econ Financ 29: 122126.

20. Kasuga $\mathrm{H}$ (2004) Saving-investment correlations in developing countries. Econ Lett 83: 371-376.

21. Guiso L, Sapienza P, Zingales L (2004) Does Local Financial Development Matter? Q J Econ 929-969.

22. Barra C, Destefenis S, Lubrano Lavadera G (2013) Financial Development and Economic Growth : Evidence from Highly Disaggregated Italian Data.

23. Wong $D$ (1990) What do saving-investment relationships tell us about capital mobility?. J Int Money Financ 9: 60-74. 